\title{
Urgensi Pencegahan Tindak Pidana Curang (Fraud) Dalam Klaim Asuransi
}

\author{
Urgency of Fraud Prevention in Insurance Claims
}

\author{
Syukri Kurniawan', Hari Sutra Disemadi², Ani Purwanti \\ 1. Fakultas Hukum Universitas Diponegoro, Indonesia. E-mail: syukrikurniawan28@gmail.com \\ 2. Fakultas Hukum Universitas Diponegoro, Indonesia. E-mail: haridisemadi@gmail.com \\ 3. Fakultas Hukum Universitas Diponegoro, Indonesia. E-mail: ani purwanti81@gmail.com
}

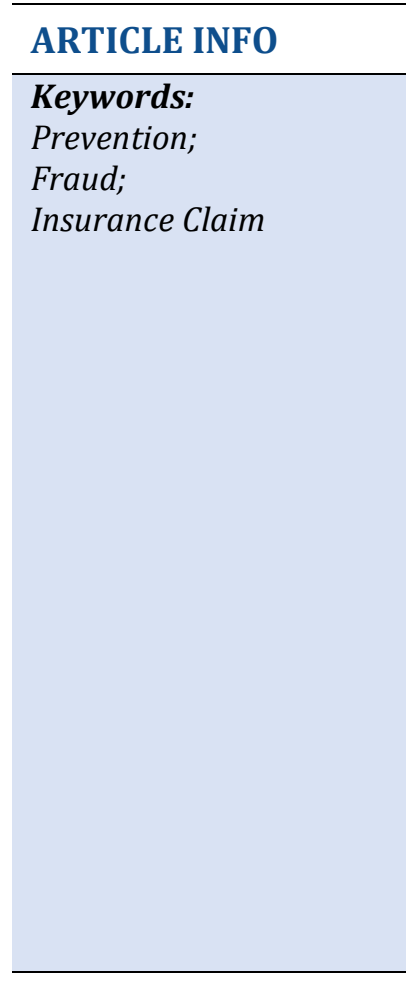

\section{INFO ARTIKEL}

\section{Kata kunci: Pencegahan; Curang; Klaim Asuransi}

\begin{abstract}
Insurance is a special agreement and can not be separated from the legal field, because in an insurance claim submission by the insured can lead to an insurance, namely fraud (fraud), in the insurance arena known as Insurance Fraud. This article discusses matters relating to the pattern or modus operandi of fraud in insurance claims and formulates a fraud strategy policy on insurance claims. This research uses doctrinal law research. Legal information sources use primary legal materials (relevant regulations and documents) for subsequent qualitative licensing analysis. The recommendations used are invitations, conceptual analysis and participation in helping to solve the problem formulation. Fraud consideration policy in insurance claims needed for a conducive work environment. The parties, both the guarantor and the insured person must have the same commitment and good faith so that the insurance claim process can be carried out properly. Basically, the commitment and good faith are insurance company policies which are the main key in the coverage related to insurance fraud. Fraudulent practices in insurance claims can be found because there is malicious intent or mens rea to obtain material benefits in a way against the law, whether done by individuals or together. This act can only be done by people who really understand the operational procedures of insurance both data and information, namely from the beginning of the guarantee process to the complexity of the policy and the form of the agreed and unapproved policy (wide guarantee).
\end{abstract}

\section{ABSTRAK}

Asuransi merupakan suatu perjanjian khusus dan tidak terlepas dari aspek hukum, karena dalam suatu pengajuan klaim asuransi oleh tertanggung bisa menimbulkan terjadinya suatu tindak pidana yaitu kecurangan (Fraud), dalam kancah asuransi dikenal dengan istilah Insurance Fraud. Artikel ini bertujuan untuk menggali hal-hal yang berkaitan dengan pola atau modus operandi fraud pada klaim asuransidan merumuskan kebijakan strategi pencegahan fraud pada klaim asuransi. Penelitian ini menggunakan penelitian hukum doktrinal. Sumber informasi hukum menggunakan bahan hukum primer (peraturan dan dokumen relevan) untuk selanjutnya 
dilakukan analisis secara kualitatif. Pendekatan yang digunakan adalah perundang-undangan, konseptual, analisis dan perbandingan dalam membantu pemecahan rumusan masalah. Kebijakan pencegahan fraud dalam klaim asuransi diperlukan suatu lingkungan kerja yang kondusif. Para pihak, baik penanggung dan tertanggung asuransi harus mempunyai komitmen serta iktikad baik yang sama agar kebijaksanaan untuk proses klaim asuransi dapat dilaksanakan dengan baik. Pada dasarnya komitmen dan itikad baik tersebut terdapat suatu kebijakan perusahaan asuransi yang merupakan kunci utama dalam mencegah serta mendeteksi fraud atas klaim asuransi. Praktik fraud dalam klaim asuransi biasanya ditemukan karena adanya niat jahat atau mens rea untuk memperoleh keuntungan materi dengan cara melawan hukum, baik dilakukan oleh individu atau bersamasama. Perbuatan ini hanya bisa dilakukan oleh orang-orang yang sangat mengerti prosedur operasional asuransi baik data maupun informasi yaitu dari awal proses underwriting sampai dengan munculnya polis dan bentuk dari peristiwa yang dijamin serta tidak dijamin polis (luas jaminan).

\section{Pendahuluan}

Kebutuhan akan asuransi pada perkembangan ekonomi yang modern saat ini banyak diminati oleh masyarakat. Semua orang dalam perjalanan hidupnya pasti mengalami risiko yang bisa terjadi pada diri mereka baik dari datangnya ketidaksengajaan maupun dari kecerobohannya. Manusia selalu berusaha mencegah ataupun menanggulangi risiko yang mungkin akan terjadi pada dirinya. Pentingnya sebuah perlindungan bagi masyarakat dapat dipahami dengan berbagai jenis risiko yang bisa terjadi pada diri mereka adalah salah satu penyebab tingginya jumlah pengguna asuransi saat ini.

Perkembangan industri perasuransian yang di dukung dengan teknologi yang maju serta kebutuhan ekonomi yang semakin meningkat tidak terlepas dari kemungkinan adanya perbuatan-perbuatan yang dilarang oleh hukum. Perbuatan yang terlarang itu adalah tindak pidana. Asuransi merupakan suatu perjanjian khusus yang tidak terlepas dari aspek hukum, karena suatu penutupan asuransi bisa menimbulkan terjadinya tindak pidana. Dokumen polis tidak hanya dianggap sebagai perjanjian asuransi yang menjamin timbulnya kerugian, namun yang harus diperhatikan suatu risiko tersebut dapat terjamin atau tidaknya serta pembayaran premi yang diperjanjikan kedua belah pihak dapat dilaksanakan. Apabila tertanggung mendapatkan suatu musibah atau kerugian maka haknya di dalam polis mendapatkan penggantian klaim asuransi.

Perjanjian asuransi dapat memunculkan bentuk kejahatan baru yang merupakan kejahatan kerah putih dalam bisnis asuransi yaitu kecurangan, dalam kancah asuransi dikenal dengan istilah Insurance Fraud. ${ }^{1}$ Di dalam aturan hukum pidana Indonesia perbuatan curang atau fraud dalam industri asuransi dikategorikan sama dengan tindak pidana penipuan yang diatur di Pasal 378, 381 dan Pasal 382 Kitab Undang-Undang Hukum Pidana (KUHP). Praktik fraud sendiri sudah berlangsung lama di industri asuransi,

1 Ridha Ari Setyono, "Tinjauan Kriminologi Dan Hukum Pidana Mengenai Kejahatan Dalam Kegiatan Asuransi," Jurnal Hukum Khaira Ummah 12, no. 4 (2017): 968. 
bahkan pola ataupun modus kecurangan klaim ini terus berjalan dengan perkembangan asuransi.

Di industri asuransi fraud adalah suatu tindak pidana yang dilakukan oleh nasabah (tertanggung) atau pihak ketiga dengan cara melawan hukum terhadap perusahaan asuransi dengan tujuan untuk memperoleh keuntungan finansial secara tidak sah dari penutupan risiko. Contoh kasus yang pernah terjadi pada tahun 2018 adalah kebakaran pabrik yang ada di Mojokerto. Saat itu pemilik pabrik mengklaim ke perusahaan asuransi atas kejadian tersebut. Hasil dari investigasi menunjukkan bahwa kebakaran itu disengaja oleh pemilik pabrik untuk mendapatkan klaim yang besar senilai Rp 20 miliar. ${ }^{2}$ Masalah fraud memang unik di dunia asuransi, karena perbuatan tersebut sedikit sulit dilihat secara nyata. Bagi perusahaan asuransi masalah fraud merupakan hal yang tidak biasa terjadi. Adapun hak dari perusahaan asuransi ingin mendapatkan premi dari tertanggung, tapi di sisi lain terkadang tertanggung mengajukan klaim yang tidak wajar serta merekayasanya. Dalam perkembangannya tertanggung terkadang jauh lebih pandai dari karyawan asuransinya, ini tentunya membuat perusahaan asuransi menjadi bingung dan merugi akibat perbuatannya.

Saat ini dunia perasuransian di Indonesia dinyatakan darurat fraud, sebab Asosiasi Asuransi Umum Indonesia (AAUI) mendapati banyak kasus kecurangan atas klaim mengakibatkan industri asuransi bisa merugi miliaran rupiah setiap tahunnya. Kerugian ini disebabkan tindakan fraud yang dilakukan sejumlah nasabah. ${ }^{3}$ Banyaknya kasus kecurangan ini membuktikan bahwa adanya kegagalan audit atas klaim asuransi karena belum mampu mencegah dan mendeteksi adanya kecurangan. Perbuatan yang terlarang ini jangan sampai dibiarkan terus-menerus karena akan menimbulkan praktik-praktik yang dapat menghancurkan tatanan industri asuransi serta merusak "Record asuransi nasional" di mata reasuradur luar negeri. Agar praktik ini tidak terus terjadi, maka perusahaan asuransi harus melakukan upaya antisipasi serta mengoptimalkan fungsi pencegahannya terutama untuk menghadapi tertanggung yang berniat kurang baik ketika melakukan klaim asuransi.

\section{Metode Penelitian}

Penelitian ini menggunakan penelitian hukum doktrinal. Sumber informasi hukum menggunakan bahan hukum primer (peraturan dan dokumen relevan) untuk selanjutnya dilakukan analisis secara kualitatif. Pendekatan yang digunakan adalah perundangundangan, konseptual, analisis, dan perbandingan dalam membantu pemecahan rumusan masalah. Sumber data penelitian ini, terdiri dari bahan hukum primer, bahan hukum sekunder untuk dilanjutkan dengan menganalisis secara keseluruhan, terhadap peraturan

2 Caroline Damanik, "Pemilik Toko Bakar Tokonya Sendiri demi Klaim Asuransi Rp 20 Miliar," Kompas.com, diakses Januari 5, 2020, https://regional.kompas.com/read/2018/06/22/09321081/pemilik-tokobakar-tokonya-sendiri-demi-klaim-asuransi-rp-20-miliar.

3 "Industri Asuransi Sebut Rugi Miliaran Akibat Fraud Nasabah," CNN Indonesia, diakses Januari 15, 2020, https://www.cnnindonesia.com/ekonomi/20190523211010-78-397948/industri-asuransi-sebut-rugimiliaran-akibat-fraud-nasabah. 
perundang-undangan, literatur, data, dan beberapa dokumen yang terkait, serta bahan hukum tersier untuk menjelaskan dan membantu dalam menganalisis bahan hukum primer maupun sekunder.

\section{Analisis Dan Pembahasan}

\subsection{Pengaturan Hukum Mengenai Penyelenggaraan Perasuransian Di Indonesia}

Pengaturan mengenai asuransi dapat ditemukan dalam berbagai peraturan perudangundangan di antaranya: 4

1. Pengaturan asuransi di dalam Kitab Undang-Undang Hukum Dagang (KUHD) terdapat dua cara pengaturan yakni pengaturan secara umum dan khusus. Pengaturan secara umum dapat ditemukan di Buku I Bab 9 Pasal 246-286 KUHD berlaku untuk semua jenis asuransi. Sedangkan pengaturan secara khusus dapat ditemukan dalam di Buku I Bab 10 Pasal 287-308 KUHD dan Buku II Bab 9 dan Bab 10 Pasal 592-695 KUHD lebih jelasnya sebagai berikut:

a. Asuransi kebakaran Pasal 287-298 KUHD;

b. Asuransi hasil pertanian Pasal 299-301 KUHD;

c. Asuransi jiwa Pasal 302308 KUHD;

d. Asuransi pengangkutan laut dan perbudakan Pasal 592-685 KUHD;

e. Asuransi pengangkutan darat, sungai dan perairan pedalaman Pasal 686-695 KUHD.

Pengaturan asuransi dalam KUHD memprioritaskan aspek keperdataan pada dasarnya yakni perjanjian antara tertanggung dan penanggung. Perjanjian tersebut melahirkan kewajiban dan hak bagi tertanggung dan penanggung secara timbal balik. Sebagai perjanjian khusus, asuransi dibuat dalam bentuk tertulis berupa akta atau dikenal dengan polis asuransi.

2. Terdapat dalam Undang-Undang Nomor 2 Tahun 1992 Tentang Usaha Perasuransian Lembaga Negara (UU No. 2 Tahun 1992). Di dalam KUHD pengaturan asuransi memprioritaskan aspek keperdataan sedangkan UU No. 2 Tahun 1992 lebih memprioritaskan pengaturan asuransi pada aspek bisnis dan administratif, apabila dilanggar akan dikenai sanksi pidana administratif.

Diberlakukannya Undang-undang Nomor 2 Tahun 1992 tentang Usaha Perasuransian yang kemudian diubah menjadi UU No. 40 Tahun 2014, tentang Perasuransian, maka dianggap cukup layak aturan hukum yang mengatur tentang usaha perasuransian, baik dari aspek keperdataan maupun dari aspek publik administratif. Kedua undang-undang ini selalu dijadikan dasar dari beberapa penetapan peraturan mengenai asuransi yang berlaku di Indonesia. Dapat dikatakan Undang-Undang Nomor 2 Tahun 1992 yang kemudian diganti menjadi UU No. 40 Tahun 2014 merupakan dasar hukum utama yang mengatur dan menegaskan semua aktivitas asuransi. Adapun pertimbangannya untuk

4 Djoko Prakoso dan I Ketut Murtika, Hukum Asuransi Indonesia (Jakarta: Bina Aksara, 1987), 115. 
melaksanakan ketentuan Pasal 5 ayat (3), Pasal 18 ayat (4), Pasal 26 ayat (2), Pasal 28 ayat (6), Pasal 29 ayat (5), Pasal 31 ayat (5), dan Pasal 39 ayat (3) Undang-Undang Nomor 40 Tahun 2014 tentang Perasuransian, membutuhkan penetapan Peraturan Otoritas Jasa Keuangan tentang Penyelenggaraan Usaha Perusahaan Asuransi, Perusahaan Asuransi Syariah, Perusahaan Reasuransi, dan Perusahaan Reasuransi Syariah.

\subsection{Tinjauan Tentang Asuransi Dan Klaim Asuransi}

Secara bahasa, asuransi adalah jaminan atau pertanggungan. Sedangkan menurut istilah, asuransi adalah jaminan atau pertanggungan yang diberikan oleh penanggung kepada yang ditanggung untuk risiko kerugian sebagaimana diterapkan dalam polis (surat perjanjian) bila terjadi kebakaran, kecurian, kerusakan, kematian atau kecelakaan lainnya dengan pertanggungan membayar premi sebanyak yang ditentukan kepada penanggung tiap bulan. ${ }^{5}$

Menurut Abbas Salim, asuransi adalah suatu keinginan untuk menetapkan kerugiankerugian kecil yang sudah pasti sebagai pengganti (substitusi) kerugian-kerugian besar yang belum pasti. Tujuan asuransi itu sendiri adalah untuk memindahkan risiko dari individu (tertanggung) kepada perusahaan asuransi (penanggung). Adapun tujuan pertanggungan terutama untuk mengurangi dan menghindari risiko-risiko yang kita jumpai dalam masyarakat. 6

Pengertian asuransi juga dapat ditemukan dalam Pasal 246 KUHD maupun Pasal 1 ayat (1) Undang-Undang Nomor 40 Tahun 2014 tentang Usaha Perasuransian (UU Perasuransian), pada dasarnya asuransi atau pertanggungan adalah perjanjian antara penanggung dan tertanggung atas suatu risiko yang dijaminkan merupakan bisnis yang sangat bergantung pada asas kepercayaan antara perusahaan asuransi (penanggung) dengan pemegang polis (tertanggung), dimana pihak penanggung membayarkan sejumlah manfaat (pertanggungan) kepada tertanggung sesuai dengan apa yang tertulis dalam polis asuransi dan untuk itu tertanggung melimpahkan kerugian yang mungkin dialaminya di masa mendatang kepada penanggung.

Perjanjian asuransi perlu dilandasi dengan prinsip-prinsip atau asas-asas asuransi dengan meliputi semua kebutuhan yang akan dilindungi. Adapun prinsip-prinsip pokok asuransi sebagai berikut: ${ }^{7}$

1. Prinsip kepentingan yang dapat diasuransikan (principle of Insurable Interest) Maksud dari prinsip ini adalah untuk mencegah asuransi dari bahaya moral yang tinggi serta mencegah perjudian. Jika tidak terdapat ketentuan tersebut, maka ia seseorang yang tidak mempunyai kepentingan terhadap suatu objek asuransi, akan dapat menutup asuransi terhadap objek tersebut. Dampaknya, orang yang tidak mengalami

5 Huzaimah Tahido Yanggo, Masail Fiqhiyah: Kajian Hukum Islam Kontemporer (Bandung: Angkasa, 2005), 13.

6 Abbas Salim, Asuransi dan Manajemen Risiko (Jakarta: Raja Grafindo Persada, 2007), 1.

7 Sonni Dwi Harsono, Prinsip-Prinsip dan Praktik Asuransi, Yayasan Pengembangan Ilmu Asuransi (Jakarta: Jakarta Insurance Institute, 2005), 69. 
kerugian akan mendapatkan ganti kerugian apabila terjadi musibah atau risiko yang menimpa objek tersebut. Prinsip dasar dari insuranble interest adalah menghindarkan industri asuransi dari perjudian.

2. Prinsip itikad yang terbaik dan jujur (principle of utmost good faith)

Prinsip dimaksudkan agar para pihak baik tertanggung maupun penanggung diharuskan memberitahu segala hal dan keterangan yang sebenar-benarnya, sejujurjujurnya dan selengkap-lengkapnya perihal semua informasi saat pembuatan perjanjian asuransi. Sejak awal kewajiban dari tertanggung adalah mengajukan permohonan penutupan maupun selama masa pertanggungan. Jika pihak tertanggung menyembunyikan keterangan-keterangan yang penting atas objek yang diasuransikan baik sengaja maupun tidak sengaja, maka pihak penanggung dapat menyembunyikan hak untuk menghentikan perjanjian asuransi.

3. Prinsip Ganti Kerugian (Principle of Indemnity)

Fungsi dari asuransi adalah mengalihkan risiko yang kemungkinan diderita atau dihadapi oleh tertanggung karena terjadi suatu peristiwa yang tidak pasti. Besarnya ganti kerugian yang akan diterima oleh tertanggung harus setara dengan kerugian yang dialaminya. Inilah inti dari prinsip ganti kerugian.

4. Prinsip Subrogasi (Principle of Subrogation)

Prinsip ini dimaksudkan agar tertanggung tidak bisa mendapatkan ganti kerugian melebihi kerugian yang dialaminya. Subrogasi adalah perubahan status tertanggung oleh penanggung yang telah membayar ganti kerugian. Adanya prinsip subrogasi, maka pihak ketiga yang menyebabkan kerugian tidak akan bebas dari tanggung jawabnya, hal ini akan dapat dituntut oleh penanggung.

5. Prinsip Kontribusi (Principle of Contribution)

Prinsip ini terjadi jika suatu objek yang diasuransikan lebih dari satu perusahaan asuransi, maka jika terjadi kerugian yang dijamin dan salah satu perusahaan asuransi sudah membayarkan penuh kerugiannya sehingga hak menuntut ganti rugi dari perusahaan lain beralih kepada perusahaan asuransi yang sudah membayar penuh penggantian kerugian tersebut.

6. Prinsip Sebab Akibat (Principle of Proxima Cause)

Prinsip ini berhubungan dengan sebab akibat, untuk menegaskan penyebab yang ditimbulkan dari kerugian tersebut dan apakah penyebab itu dijamin oleh polis asuransi. Maksud dari prinsip ini adalah perjanjian asuransi adalah penanggung bertanggungjawab terhadap kerugian yang dialami oleh tertanggung, jika kerugian tersebut memang menjadi tanggung jawab penanggung. Jika tidak, maka penanggung bisa dibebaskan dari kewajibannya membayar ganti kerugian yang bukan menjadi tanggung jawabnya.

Tertanggung yang mengalami kerugian dari sebuah peristiwa, maka dapat mengecek risikonya yang tercantum di dalam polis. Tertanggung asuransi berhak mengajukan klaim asuransi sebagai bentuk permintaan untuk pergantian rugi dari kerugian yang telah dialaminya. Kerja sama antara pemegang polis (tertanggung) dan perusahaan asuransi (penanggung) sangat dibutuhkan saat proses klaim asuransi. Penanggung berkewajiban 
memberikan klaim asuransi kepada tertanggung asuransi. Akibat peristiwa yang merugikannya, proses klaim ini mengharuskan tertanggung memberikan informasi yang benar serta dokumen yang lengkap. Setiap penanganan proses klaim penanggung berusaha menjalankan prosedur sesuai operasi standar. Akibat peristiwa yang terjadi padanya, tertanggung dapat menutup kerugian bila membutuhkan klaim asuransi. Pencairan klaim ini dilakukan sebelum penanggung memastikan semua persyaratan sudah lengkap terpenuhi oleh tertanggung untuk penuntasan proses klaim yang sesuai dengan harapan masing-masing pihak.

Pengertian klaim asuransi adalah suatu tuntutan atau penagihan pembayaran ganti rugi atas kerugian yang dialami tertanggung kepada penanggung. Klaim asuransi merupakan suatu hak bagi tertanggung, sedangkan bagi penanggung merupakan suatu kewajiban. Proses klaim asuransi harus melewati prosedur standar yang harus dipenuhi oleh tertanggung secara lengkap dan benar. Pada praktik yang sering dilakukan sesuai aturan perundangan mengenai perasuransian dan sejumlah perusahaan asuransi, secara umum proses klaim asuransi dapat diurutkan sebagai berikut:

1. Nasabah dapat melaporkan sebuah kejadian atau musibah yang merugikan baginya disertai pengajuan klaim asuransi dengan syarat menyerahkan dokumen yang perlu ke bagian klaim;

2. Kewajiban perusahaan asuransi adalah memproses dan menerima pengajuan klaim yang dilakukan oleh nasabah;

3. Kedua belah pihak baik antara nasabah dan perusahaan asuransi bersepakat atas nilai klaim asuransi. Kesepakatan nilai dari klaim asuransi, perusahaan asuransi berkewajiban membayar nilai klaim asuransi maksimal 30 hari sejak terjadinya kesepakatan;

4. Jika dalam waktu 30 hari nasabah juga belum menerima pembayaran nilai klaim, nasabah dapat memilih penggunaan penyelesaian secara mediasi atau langsung mengajukan somasi tanpa mediasi terhadap perusahaan asuransi sebelum proses gugatan ke pengadilan;

5. Jika setelah mediasi ternyata perusahaan asuransi membayarkan klaim asuransinya, maka permasalahan selesai. Apabila perusahaan asuransi juga tetap tidak membayarkan klaim asuransi yang telah disetujui meskipun telah dilakukan mediasi ataupun somasi, maka nasabah dapat melakukan gugatan perdata ke pengadilan atas dasar wanprestasi;

6. Pengadilan memutuskan perkara wanprestasi tersebut. Selanjutnya, nasabah dan perusahaan asuransi melaksanakan keputusan pengadilan. ${ }^{8}$

Saat suatu musibah atau kejadian yang tidak terduga terjadi, tertanggung asuransi pasti sangat berharap bisa memperoleh haknya sesuai polis dengan mengajukan klaim. Ada kalanya pihak asuransi menolak klaim dari jenis asuransi tersebut. Tentu kejadian ini sangat mengecewakan. Ada beberapa faktor penyebab klaim ditolak, antara lain: saat

8 Florentinus Nugro Hardianto, "Pemodelan Sengketa Klaim Asuransi di Indonesia: Pendekatan Game Theory," Bina Ekonomi 21, no. 2 (2017): 163. 
mengisi proposal permintaan asuransi terjadi kesalahan yang dilakukan oleh nasabah; kerugian atau risiko yang dialami nasabah tidak disebutkan dalam polis, karena nasabah belum melakukan kewajibannya pada perusahaan asuransi contohnya lalai atau tidak tepat waktu dalam membayar premi; Pengajuan klaim terjadi di luar periode polis sebelum masa pertanggungan mulai atau sesudah masa pertanggungan berakhir; terlambatnya nasabah melaporkan klaim ke perusahaan asuransi; nasabah tidak dapat menunjukkan barang bukti; perusahaan asuransi sebelum memutuskan pembayaran klaim tidak diberi kesempatan untuk melakukan survei atau investigasi. ${ }^{9}$

\subsection{Modus Operandi Tindak Pidana Kecurangan (Fraud) Dalam Klaim Asuransi}

Kecurangan asuransi dalam proses klaim asuransi akan menimbulkan sengketa klaim asuransi. Ketika tertanggung atau pihak ketiga melakukan kecurangan asuransi yang dilakukan secara sengaja untuk mendapatkan sejumlah manfaat dengan cara melawan hukum pada saat pembelian, penggunaan, penjualan atau peminjaman asuransi. ${ }^{10}$ Menurut Karapiperi membagi kecurangan dalam klaim asuransi menjadi dua yaitu soft fraud dan hard fraud. Kecurangan yang mengarah secara administratif disebut soft fraud, sedangkan kecurangan yang menandakan adanya tindak pidana disebut hard fraud. ${ }^{11}$

Secara teoritis dikutip dari Departement of Justice Care Amerika Serikat tahun 1998, yang menyatakan ada tiga faktor penyebab terjadinya fraud antara lain: kebutuhan (need) situasi dimana pemegang polis dan/atau tertanggung sebelum terjadinya kerugian sedang mengalami kesulitan keuangan; kesempatan (opportunity), misalnya ada celah hukum yang dapat dimanfaatkan oleh pemegang polis dan/atau tertanggung sulit ditelusuri penyebab kerugiannya untuk mengajukan klaim fiktif; keserakahan (greed) sikap yang memandang tindakan fraud sebagai suatu pembenaran yang sesuai dengan kode etik. ${ }^{12}$

Praktik fraud dalam klaim asuransi biasanya ditemukan karena adanya niat jahat atau mens rea untuk memperoleh keuntungan materi dengan cara melawan hukum, baik dilakukan oleh individu atau bersama-sama. Perbuatan ini hanya bisa dilakukan oleh orang-orang yang sangat mengerti prosedur operasional asuransi baik data maupun informasi yaitu dari awal proses underwriting sampai dengan munculnya polis dan bentuk dari peristiwa yang dijamin serta tidak dijamin polis (luas jaminan). Semua itu merupakan

9 Sri Handayani, "Pengaruh Penyelesaian Klain Asuransi Terhadap Pencapaian Target Penjualan Produk Asuransi AJB Bumiputera1912 Cabang Bengkulu," EKOMBIS REVIEW: Jurnal Ilmiah Ekonomi dan Bisnis 5, no. 1 (Januari 21, 2017): 82, https://jurnal.unived.ac.id/index.php/er/article/view/332.

10 Firas Mohammad Al Rawashdeh and Omar Al Singlawi, "The Existence of Fraud Indicators in Insurance Industry: Case of Jordan", International Journal of Economics and Financial Issues, 6(6S), 168-176 (2016): 172.

11 D. Karapiperis, "Insurance Fraud" <https://www.naic.org/cipr_newsletter_archive/vol13_ insurance_fraud.pdf>, diakses pada 15 Januari 2020

12 Mohammad Zaini, Anita Carolina, dan Achdiar Redy Setiawan, "Analisis Pengaruh Fraud Diamond Dan Gone Theory Terhadap Academic Fraud (Studi Kasus Mahasiswa Akuntansi Se-Madura)", Simposium Nasional Akuntansi XVIII, 1-20, (2015): 8. 
bagian dari proses klaim asuransi. Menurut Sendra kecurangan dalam asuransi dapat dikelompokkan menjadi tiga aspek pokok yaitu dari aspek pelaku, waktu, dan perilaku. ${ }^{13}$

Aspek pelaku kejahatan (fraudsters) terbagi atas dua yaitu internal fraud dan eksternal fraud. Internal fraud yaitu kecurangan yang dibuat oleh perusahaan asuransi seperti insurer, agen, pialang, dan karyawan lainnya, sedangkan external fraud yaitu kecurangan yang dibuat oleh pihak di luar perusahaan asuransi, seperti tertanggung ataupun pemegang polis. Jika pihak-pihak internal perusahaan asuransi melakukan kecurangan asuransi yang dilakukan secara bersama-sama yang mempunyai insurable interest terhadap objek asuransi yang dipertanggungkan, maka akan mempersulit perusahaan asuransi untuk memverifikasi klaim asuransi dengan benar.

Kemudian aspek waktu yaitu kecurangan yang ditemukan pada fase proses asuransi (Underwriting fraud). Kecurangan ini dapat ditemukan saat proses underwriting coverage dan kontrak asuransi diperpanjang. Termuat di dalam bentuk ini adalah application fraud, premium fraud, dan perbuatan secara sengaja untuk memalsukan kontrak asuransi. Pada tahap inilah yang merupakan bentuk kecurangan yang paling sering terjadi saat proses klaim, sehingga pada fase inilah yang disebut dengan istilah insurance fraud, misalnya adanya pihak yang mengajukan klaim fiktif dengan cara menaikkan nilai klaim dalam batas yang tidak wajar, memanipulasi klaim asuransi, dan sebagainya.

Selanjutnya aspek perilaku, yaitu karena adanya iktikad atau motivasi. Bentuk kecurangan ini terbagi atas dua yaitu opportunistic fraud atau soft fraud dan planned fraud atau hard fraud. Opportunistic fraud merupakan sikap oportunistis negatif orang yang normalnya bersikap jujur. jenis perbuatan oportunistis dalam kelompok ini tergantung pada sudut pandang masyarakat yang mengukurnya. Namun, seacara umum jenis fraud ini mengarah pada perbuatan yang memanfaatkan kesempatan untuk menaikkan nilai kerugian dari nilai yang sebenarnya sewaktu mengajukan klaim. Sedangkan Planned fraud merupakan kecurangan yang telah dipersiapkan dan perbuatannya dapat mengarah pada tindak pidana, yang dapat dilakukan baik secara perseorangan maupun kelompok yang terorganisir. Peluang seseorang untuk melancarkan aksi kecurangan asuransi sangat mungkin terjadi. Para pihak yang terikat kontrak berkewajiban agar saling beriktikad baik (good faith), baik dalam hal menyampaikan informasi yang perlu bagi kesepakatan kedua belah pihak. Tidak adanya iktikad baik dari para pihak bisa menimbulkan terjadinya insurance fraud.

Itikad baik dalam tahap melaksanakan perjanjian adalah kepatutan, yaitu suatu penilaian baik terhadap perbuatan suatu pihak dalam melaksanakan apa yang akan diperjanjikan. Maksud dari asas iktikad baik adalah kebebasan suatu pihak dalam membuat perjanjian tidak dapat diwujudkan sekehendaknya tetapi dibatasi oleh itikad baiknya. Setiap kontrak asuransi diharuskan memiliki prinsip mendasar yaitu asas iktikad baik.

13 Ketut Sendra, Klaim Asuransi: Gampang, (Jakarta: Badan Mediasi Asuransi Indonesia (BMAI) Bersama Penerbit PPM, 2009), 35-39. 
Sejatinya, fungsi dari sebuah asuransi adalah sebagai alat proteksi. Namun, ada saja oknum yang memanfaatkan asuransi untuk mendapatkan keuntungan materi dengan melakukan kecurangan. Berikut ini beberapa modus operandi kecurangan klaim asuransi yang umum terjadi:

1. Pemalsuan Dokumen

Pemalsuan dokumen bisa berupa pemalsuan identitas, surat kematian, dan dokumendokumen pendukung yang disertakan dalam proses klaim. Perusahaan menemukan modus manipulasi klaim asuransi disertai pemalsuan dokumen identitas diri setelah melakukan investigasi. Pemalsuan dokumen juga kerap terjadi pada asuransi marine cargo, seperti dokumen kepemilikan, izin ekspor, sertifikat asal, dokumen-dokumen lain terkait kargo dan dokumen dari pihak otoritas terkait.

2. Klaim yang telah direncanakan sebelumnya

Merencanakan pemalsuan berupa klaim atas kejadian atau insiden yang di-cover oleh polis asuransi. Contohnya, kecelakaan mobil yang dibuat-buat, membakar properti dengan sengaja, melukai diri sendiri, menenggelamkan kapal dengan sengaja, atau melukai bahkan membunuh seseorang (yang diasuransikan) untuk mendapatkan uang asuransi.

3. Nilai klaim yang dibesar-besarkan

Nilai klaim yang sengaja diperbesar biasanya dilakukan oleh tertanggung asuransi yang bekerja sama dengan pihak ketiga. Biasanya modus ini diikuti dengan modus pemalsuan invoice. Contohnya, pihak tertanggung bekerja sama dengan dokter dan pihak rumah sakit untuk memasukkan tagihan tindakan medis yang sebenarnya tak dilakukan. Bisa pula pihak rumah sakit memberikan tindakan medis yang sebenarnya tak perlu. Dalam hal ini tertanggung atau pasien tak tahu jika dirinya sedang dimanipulasi.

4. Pemalsuan Invoice

Invoice diperlukan untuk mengklaim asuransi. Modus ini biasanya tidak dilakukan sendiri oleh pelaku kecurangan. Misalnya, pelaku bekerja sama dengan pihak ketiga untuk menerbitkan invoice palsu. Nilai pembelian yang dilakukan tertanggung asuransi tidak sebesar nilai yang tertera dalam invoice tersebut. ${ }^{14}$

Setelah mengetahui modus kejahatan yang disertai dengan motif kejahatannya, maka faktor penyebab terjadinya insurance fraud dapat dianalisis berdasarkan ilmu kriminologi adalah para pelaku melakukan insurance fraud dengan cara sedemikian rupa, sehingga korban tidak mengetahui perbuatan dan pelaku kejahatan pada saat perbuatan tersebut dilakukan. Hal inilah yang menjadi sebab terjadinya tindak pidana kecurangan dalam klaim asuransi. Pelaku melakukan tipu muslihat serta serangkaian kebohongankebohongan, namun korban tidak mengetahui perbuatan tersebut karena pelaku melakukannya dengan sedemikian rupa agar tidak ketahuan. Dengan demikian, pelaku

14 Azizah Nur Alfi, "Modus yang Digunakan Untuk Manipulasi Klaim Asuransi," Bisnis.com, diakses Januari 5, 2020, https://finansial.bisnis.com/read/20180322/215/752823/ini-modus-yang-digunakan-untukmanipulasi-klaim-asuransi. 
memiliki kesempatan dan celah untuk melakukan kejahatan terhadap korban yang sulit ditelusuri untuk dimanfaatkan mengajukan klaim fiktif.

Perlu diperhatikan saat terjadi klaim, nasabah harus memberikan informasi yang benar dan jelas mengenai insiden yang dialaminya, karena berkaitan dengan kelanjutan proses klaim ke depannya. Saat mengajukan klaim juga sangat mungkin terdapat kesalahan dalam memberikan informasi terkait insiden maupun besaran kerugian yang dialami. Namun, jangan sampai kesalahan tersebut sengaja nasabah lakukan dalam mengajukan klaim. Tentunya pihak asuransi dengan mudahnya menemukan modus seperti ini berdasarkan pengalaman mereka sebelumnya. Kesengajaan tersebut pastinya klaim akan ditolak baik sebagian atau seluruhnya berdasarkan hasil verifikasi yang dilakukan.

\subsection{Kebijakan Dan Strategi Pencegahan Praktik Fraud Dalam Klaim Asuransi}

Tidak ada satu pun instansi, lembaga dan organisasi yang terbebas dari fraud termasuk perusahaan asuransi, karena hal ini kembali kepada manusianya. Seperti apa pun bentuk aturan dan prosedur yang telah disusun sangat dipengaruhi oleh manusia yang menjalankannya, karena tidak semua manusia punya sikap jujur dan berintegritas tinggi. Maka dari itu harus ada cara pencegahan yang dapat menekan terjadinya fraud atas klaim pada industri asuransi. Bentuk pencegahan fraud dalam klaim asuransi merupakan upaya yang terintegrasi untuk menekan terjadinya fraud yaitu memperkecil peluang terjadinya kesempatan berbuat curang dan menghilangkan alasan untuk membuat pembenaran atas tindak kecurangan yang dilakukan.

Menurut Penulis kebijakan pencegahan fraud dalam klaim asuransi membutuhkan lingkungan kerja yang kondusif. Para pihak, baik penanggung dan tertanggung asuransi harus mempunyai komitmen serta itikad baik yang sama agar kebijaksanaan untuk klaim asuransi dapat dilaksanakan dengan baik. Pada dasarnya komitmen tersebut terdapat suatu kebijakan perusahaan asuransi yang merupakan kunci utama dalam mencegah serta mendeteksi fraud. Kebijakan tersebut harus dilengkapi dengan prosedur pengendalian secara tertulis dan ditetapkan secara baku sebagai media mendukung. Secara umum prosedur pencegahan harus memuat pengendalian internal, di antaranya adalah pemisahan fungsi sehingga tercipta kondisi saling cek antar fungsi dan sistem operasi yang memadai bagi sistem komputer sehingga memungkinkan komputer tersebut dapat mendeteksi fraud secara otomatis.

Langkah penting yang harus dilakukan untuk mengetahui ada atau tidaknya fraud dalam klaim asuransi adalah dengan cara mendeteksinya. Pendeteksian fraud dalam klaim asuransi oleh auditor merupakan pengidentifikasian penilaian-penilaian kecurangan yang dibuat mengacu kepada kendali-kendali yang telah ditetapkan oleh manajemen, pengujian yang dilakukan oleh auditor dan sumber-sumber lainnya baik dari dalam maupun di luar perusahaan asuransi. Sejauh ini strategi pencegahan fraud oleh AAUI tengah menggencarkan AAUI checking (pemeriksaan Asosiasi Asuransi Umum Indonesia) yang dibuat sejak Desember 2016. Program ini digunakan untuk memeriksa nasabah atau tertanggung asuransi yang berpotensi melakukan kecurangan dalam klaim asuransi. 
Upaya ini akan efektif jika terdapat pertukaran informasi data calon nasabah, misalnya dalam bentuk "Daftar hitam" nasabah asuransi. Upaya ini sudah lama dilakukan di negara maju seperti Jepang. Negara ini melakukan kompilasi data dan pertukaran informasi sesama perusahaan asuransi bila ada kecenderungan dan kecurigaan fraud. Data tersebut mencakup kontrak, data klaim, data pemegang polis, dan objek asuransi, yang diakses terbatas hanya pada kalangan tertentu saja.

Otoritas Jasa Keuangan (OJK) sebagai lembaga tertinggi di Indonesia yang menangani masalah kecurangan pada lembaga keuangan termasuk industri asuransi, OJK telah menerbitkan dan mengatur upaya mencegah timbulnya fraud. Kebijakan tersebut adalah aturan mengenai pengendalian fraud dan penerapan strategi anti fraud bagi perusahaan asuransi dan perusahaan reasuransi. Peraturan ini tertuang dalam Surat Edaran Otoritas Jasa Keuangan atau SE OJK No. 46/2017 tentang pengendalian fraud, penerapan fraud, dan laporan strategi anti fraud bagi perusahaan asuransi syariah, perusahaan reasuransi, perusahaan reasuransi syariah, atau unit syariah. Aturan itu diterbitkan sebagai aturan turunan dari Peraturan OJK atau POJK No. 69/2016 tentang Penyelenggaraan Usaha Perusahaan Asuransi. Beberapa poin penting mengenai anti fraud yang tertuang dalam SE OJK No.46/2017 antara lain:

a. perusahaan asuransi diwajibkan melaksanakan pengendalian fraud yang meliputi aspek pengawasan aktif manajemen, organisasi dan pertanggungjawaban, pengendalian dan pemantauan, serta edukasi dan pelatihan;

b. Perusahaan asuransi diwajibkan menerapkan strategi anti fraud yang meliputi pencegahan, deteksi, investigasi, pelaporan, sanksi, serta pemantauan, evaluasi, dan tindak lanjut;

c. Perusahaan asuransi diwajibkan memberikan laporan strategi anti fraud kepada OJK. Adapun, penyampaian laporan dapat dilakukan secara online melalui sistem jaringan komunikasi data, ataupun melalui alamat email yang telah ditetapkan 0JK.

Di negara lain seperti Amerika Serikat, regulasi dan pencegahan fraud di negara tersebut terhadap suatu organisasi atau institusi termasuk perusahaan asuransi relatif ketat. Adanya aturan untuk membedakan mana perbuatan yang dikategorikan fraud atau tidak supaya memberikan batasan atau standar yang jelas. Selain itu, investigasi terhadap indikasi fraud dilakukan oleh institusi profesional dibidang investigasi yaitu Federal Bereau of Investivigation (FBI). FBI membentuk sebuah tim independen yang berguna untuk menyelidiki fraud dalam klaim asuransi. Tim ini ada di setiap provinsi. Hasil kerja tim independen ini lebih pasti dan diterima oleh pihak yang berselisih dalam perkara dugaan terjadinya fraud. ${ }^{15}$

Pencegahan fraud di Negara Inggris hampir sama dengan Amerika Serikat, Inggris juga membentuk satuan tugas khusus dibidang investigasi dalam kepolisian yaitu National Crime Agency (NCA) setara dengan FBI yang berada di bawah Badan Kejahatan Nasional Inggris. Satuan ini bertanggungjawab untuk mencegah, mengadili dan memberantas kasus

15 Info BPJS Kesehatan, Tindak Kecurangan (Fraud) Merugikan Progam JKN (Negara), <www.bpjskesehatan.go.id>, diakses pada tanggal 15 Januari 2020. 
fraud. Pemerintah Inggris juga bekerja sama dengan Lembaga Penanganan Kasus Penipuan Serius atau Serious Fraud Office (SF0) dalam melakukan penyidikan dan pencegahan sejumlah kasus penipuan keuangan.

Berbeda dengan Negara Finlandia, negara ini mempunyai cara lain dan memandang fraud sebagai tindak pidana khusus, sehingga tidak diperlukan kebijakan khusus untuk menanggulangi tindak pidana fraud. Walaupun sikap anti fraud tetap dimasukkan dalam kebijakan umum. Masyarakat Finlandia dikenal sangat menjunjung tinggi etika dan kejujuran. Kejujuran dianggap penting karena kepercayaan adalah suatu hal yang utama menurut masyarakat Finlandia. Bagi mereka kehilangan kepercayaan berarti kehilangan alasan untuk terus bertahan. Hukum bukan untuk dilanggar melainkan masyarakatnya sangat taat terhadap hukum. Pelanggaran terhadap hukum menimbulkan rasa malu, tidak terkecuali fraud. Sikap masyarakat yang sangat anti fraud ini berdampak pada kontrol sosial yang tinggi, sementara pengawasan yang terbaik terhadap pemerintahan adalah kontrol sosial yang dilakukan masyarakat.

Dari ketiga negara tersebut, perusahaan asuransi nasional atau instansi terkait seperti 0JK bisa mencontoh penerapan sistem anti fraud yang efisien baik dari aturan yang mereka gunakan, sistem investigasi, serta budaya anti fraud yang bisa diadopsi, disesuaikan, dan digunakan di Indonesia. Kesadaran semua pihak terhadap fraud sangatlah penting. Para pihak terkait jangan sampai tidak menyadari adanya potensi fraud, apalagi menyangkalnya. Jika kesadaran itu tidak ada maka akan menimbulkan kerugian karena fraud terus terjadi. Akibatnya klaim yang di bayarkan perusahaan asuransi sangat besar sehingga membuat kesehatan keuangan perusahaan asuransi menjadi buruk.

Dikutip dari European Commission telah merangkum lima komponen yang wajib ada dalam upaya pengendalian fraud di berbagai institusi, termasuk perusahaan asuransi. Komponen-komponen tersebut yaitu membangun kesadaran, membuat sistem pelaporan, deteksi, investigasi, dan pemberian sanksi. Lebih jauh European Commission menyarankan upaya-upaya anti fraud ini dijalankan secara berkala mengikuti siklus yang dapat digambarkan sebagai berikut:

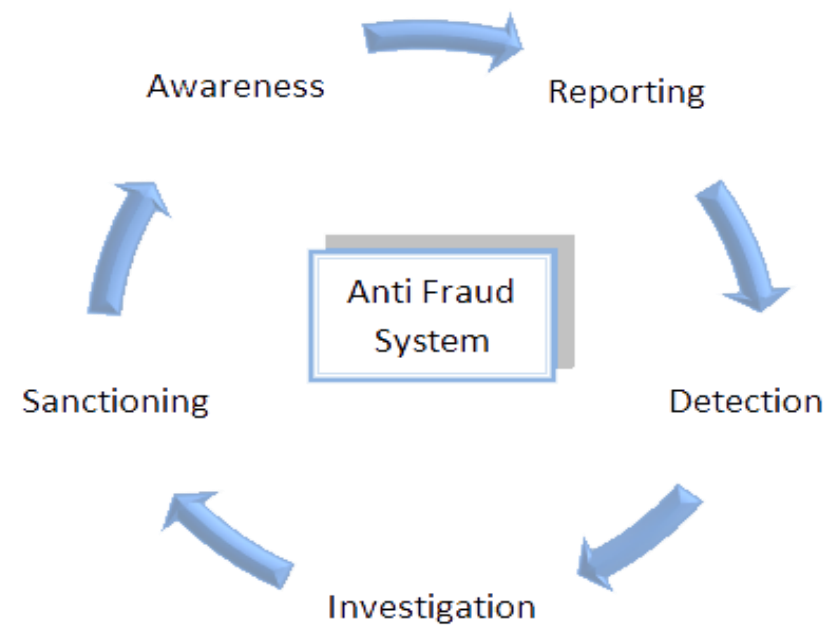

Bagan 1. Siklus Anti Fraud 
Merujuk pada siklus anti fraud yang dikembangkan oleh European Commission tahun 2013, program anti fraud ini terdiri dari lima yait ${ }^{16}$ : awareness, program ini adalah upaya membangun kesadaran para pelaku asuransi bahwa fraud adalah tindak pidana yang dapat merugikan pihak lain. Upaya ini dilakukan dengan menjalankan sosialisasi dan edukasi tentang potensi bahaya fraud; reporting, pihak yang mengetahui ada kejadian fraud di perusahaan asuransi hendaknya dapat membuat pelaporan. Perusahaan asuransi perlu menyediakan sarana dan alur pelaporan yang baik; detection, program ini merupakan upaya untuk mendeteksi secara nasional terhadap potensi fraud dan tindakan fraud. Salah satu upaya yang sedang di Indonesia adalah AAUI checking; investigation, program ini merupakan upaya untuk melakukan investigasi dalam rangka pembuktian tindakan fraud asuransi yang dalam hal ini membutuhkan campur tangan pihak berwajib; sanctioning, program ini adalah upaya pemberian sanksi administratif atau sanksi pidana terhadap pelaku fraud asuransi, sesuai dengan aturan yang berlaku.

Hal ini diperlukan suatu upaya pencegahan yang efektif untuk mengurangi kemungkinan fraud saat klaim asuransi antara lain:

1. Saat penyaringan calon nasabah

a. Memeriksa rekam jejak calon nasabah;

b. Memeriksa kembali pernyataan premi dan jenis cakupan baik yang diajukan oleh calon nasabah atau oleh agen internal.

2. Saat pemberian pelayanan kepada nasabah

a. Pengawasan aktif oleh manajemen baik terhadap internal perusahaan asuransi;

b. Komunikasi dan sosialisasi yang aktif dengan pemberi pelayanan asuransi bila ada perubahan atau pembaharuan yang menyangkut perjanjian asuransi antara perusahaan asuransi dengan nasabah.

3. Saat pengajuan klaim oleh nasabah

a. Terdapat unit khusus yang mengawasi fraud. seperti yang dilakukan oleh Badan Penyelenggara Jaminan Sosial (BPJS) Kesehatan yang membentuk unit kerja bidang manajemen utilisasi dan anti fraud bagi pelayanan kesehatan primer dan layanan rujukan di seluruh kantor cabang BPJS Kesehatan. Unit ini bertugas membangun sistem pencegahan kecurangan JKN-KIS dan memberikan sosialisasi pencegahan kecurangan kepada internal dan eksternal. BPJS Kesehatan juga mendorong seluruh pelayanan kesehatan (puskesmas, rumah sakit, klinik, dan sebagainya) membentuk tim pencegahan kecurangan;

b. Mengembangkan sistem informasi atau aplikasi yang dapat mendeteksi potensi kecurangan melalui data klaim asuransi.

4. Saat pembayaran klaim kepada nasabah

a. Memastikan transaksi pembayaran dilakukan secara transfer kepada rekening nasabah yang tertuang pada kontrak asuransi;

16 European Commission, "Work-Based Learning in Europe. Practices and Police Pointers," Education and Training (2013): 32. 
b. Melakukan monitoring dan kontrol yang rutin terhadap pembayaran klaim kepada nasabah. ${ }^{17}$

Strategi pencegahan yang sudah dirancang ataupun disusun tersebut, tetapi pelaksanaannya dilakukan dengan kurang baik akan tetap menjadi sumber atau peluang terjadinya fraud dalam klaim asuransi. Akibatnya akan menimbulkan kerugian materi bagi perusahaan asuransi. Adapun cara-cara pencegahan dan pengendalian yang efektif untuk meminimalisasi kemungkinan terjadinya fraud yakni dengan cara pembagian tugas yang jelas sehingga tidak ada satu pun yang menguasai seluruh aspek dari suatu transaksi, pengawasan ataupun kontrol yang memadai terhadap akses ke terminal komputer, serta terhadap data yang tidak ditolak dalam pemrosesan, maupun terhadap program-program serta media pendukung lainnya.

\section{Kesimpulan}

Perusahaan asuransi sangat rentan terhadap klaim yang diajukan secara curang (fraud) oleh tertanggung. Hal ini membuat perusahaan asuransi mengalami kerugian yang tidak sedikit. Praktik fraud dalam klaim asuransi biasanya ditemukan karena adanya niat jahat atau mens rea untuk memperoleh keuntungan materi dengan cara melawan hukum, baik dilakukan oleh individu atau bersama-sama. Perbuatan ini hanya bisa dilakukan oleh orang-orang yang sangat mengerti prosedur operasional asuransi baik data maupun informasi yaitu dari awal proses underwriting sampai dengan munculnya polis dan bentuk dari peristiwa yang dijamin serta tidak dijamin polis (luas jaminan) yang merupakan bagian dari proses klaim asuransi. Agar praktik ini tidak terus menerus terjadi pada perusahaan asuransi yang dapat menghancurkan tatanan industri asuransi serta merusak "Record asuransi nasional" di mata reasuradur luar negeri, maka harus dilakukan upaya antisipasi dan pencegahan secara masif. Pertama, diperlukan sebuah aturan yang tegas dan ketat selevel undang-undang agar praktik fraud klaim asuransi dapat ditekan. Kedua, memaksimalkan fungsi pengendalian fraud terutama pengawasan manajemen dengan membentuk kultur risiko, ada risk awareness yang dilakukan di internal perusahaan. Ketiga adalah dengan menyusun strategi anti fraud, ini dengan cara mengoptimalkan pendeteksian (AAUI Checking) sejak awal terhadap tertanggung. Keempat adalah adanya komitmen serta iktikad baik dari para pihak baik penanggung dan tertanggung demi terciptanya lingkungan kerja yang kondusif pada saat melaksanakan proses klaim.

\section{Daftar Pustaka}

Alfi, Azizah Nur. "Modus yang Digunakan Untuk Manipulasi Klaim Asuransi." Bisnis.com. Diakses Januari 5 , 2020. https://finansial.bisnis.com/read/20180322/215/752823/ini-modus-yangdigunakan-untuk-manipulasi-klaim-asuransi.

Damanik, Caroline. "Pemilik Toko Bakar Tokonya Sendiri demi Klaim Asuransi Rp 20

17 Ade Heryana, "Fraud dalam Asuransi Kesehatan" (Jakarta: Universitas Esa Unggul, n.d.), diakses Januari 5, 2020, https://www.academia.edu/38085466/FRAUD_DALAM_ASURANSI_KESEHATAN. 
Miliar." Kompas.com. Jiakses Januari 2020. https://regional.kompas.com/read/2018/06/22/09321081/pemilik-toko-bakartokonya-sendiri-demi-klaim-asuransi-rp-20-miliar.

European Commission. "Work-Based Learning in Europe. Practices and Police Pointers." Education and Training (2013).

Handayani, Sri. "Pengaruh Penyelesaian Klain Asuransi Terhadap Pencapaian Target Penjualan Produk Asuransi AJB Bumiputera1912 Cabang Bengkulu." EKOMBIS REVIEW: Jurnal Ilmiah Ekonomi dan Bisnis 5, no. 1 (Januari 21, 2017). https://jurnal.unived.ac.id/index.php/er/article/view/332.

Hardianto, Florentinus Nugro. "Pemodelan Sengketa Klaim Asuransi di Indonesia: Pendekatan Game Theory." Bina Ekonomi 21, no. 2 (2017): 149-165.

Harsono, Sonni Dwi. Prinsip-Prinsip dan Praktik Asuransi, Yayasan Pengembangan Ilmu Asuransi. Jakarta: Jakarta Insurance Institute, 2005.

Heryana, Ade. "Fraud dalam Asuransi Kesehatan." Jakarta: Universitas Esa Unggul, n.d. Diakses Januari 2020. https://www.academia.edu/38085466/FRAUD_DALAM_ASURANSI_KESEHATAN.

Karapiperis, D. "Insurance Fraud." Retrieved from The National Association of Insurance Commissioners (NAIC) and The Center for Insurance Policy and Research (CIPR) Newsletter 13 http://www.naic.org/cipr_newsletter_archive/vol13_insurance_fraud.pdf.

Prakoso, Djoko, dan I Ketut Murtika. Hukum Asuransi Indonesia. Jakarta: Bina Aksara, 1987.

Al Rawashdeh, Firas Mohammad, dan Omar Al Singlawi. "The Existence of Fraud Indicators in Insurance Industry: Case of Jordan." International Journal of Economics and Financial Issues 6, no. 6S (2016): 168-176.

Salim, Abbas. Asuransi dan Manajemen Risiko. Jakarta: Raja Grafindo Persada, 2007.

Sendra, Ketut. Klaim Asuransi: Gampang. Jakarta: Badan Mediasi Asuransi Indonesia (BMAI) Bersama Penerbit PPM, 2009.

Setyono, Ridha Ari. "Tinjauan Kriminologi Dan Hukum Pidana Mengenai Kejahatan Dalam Kegiatan Asuransi." Jurnal Hukum Khaira Ummah 12, no. 4 (2017): 967-974.

Yanggo, Huzaimah Tahido. Masail Fiqhiyah: Kajian Hukum Islam Kontemporer. Bandung: Angkasa, 2005.

Zaini, Mohammad, Anita Carolina, dan Achdiar Redy Setiawan. "Analisis Pengaruh Fraud Diamond dan Gone Theory Terhadap Academic Fraud (Studi Kasus Mahasiswa Akuntansi Se-Madura)." Simposium Nasional Akuntansi XVIII (2015): 1-20.

"Industri Asuransi Sebut Rugi Miliaran Akibat Fraud Nasabah." CNN Indonesia. Diakses Januari 15, 2020. https://www.cnnindonesia.com/ekonomi/20190523211010-78397948/industri-asuransi-sebut-rugi-miliaran-akibat-fraud-nasabah.

“Tindak Kecurangan (Fraud) Merugikan Progam JKN (Negara).” Info BPJS Kesehatan, 2015. 